\title{
Mosaic trisomy 4
}

INSERM

\section{Source}

INSERM. (1999). Orphanet: an online rare disease and orphan drug data base. Mosaic trisomy 4. ORPHA:96059

Mosaic Trisomy 4 is a rare autosomal anomaly, due to the presence of an extra copy of chromosome 4 in a fraction of all cells, with a variable phenotype characterized by intrauterine growth retardation, low birth weight/length/OFC, mild intellectual deficit, congenital heart defects, hypertrophic cardiomyopathy, dysmorphic features (asymmetry of the face, eyebrow anomalies, low-set, posteriorally rotated, dysplastic ears, micro-/retrog nathia), characteristic thumb abnormalities (aplasia, hypoplasia) and skin abnormalities (hypo/hyperpigmentation). Delayed puberty may be associated. 